\title{
The case of Italy: \\ Between tradition and Modernity
}

Respue quod non es, tollat sua munera cerdo. Tecum habita: noris quam sit tibi curta suppellex.

*Persius, Satire IV

The Italian people are called "Children of the Sun". They might better be called "Children of the Shadow". Their souls are dark, and nocturnal. If they are to be easy,

They must be able to hide, to be hidden in lairs

and caves of darkness. Going through these tiny, chaotic back-ways of the village was like venturing through the labyrinth made by furtive creatures (...) And I was pale, and clear, and evanescent, like the light, and they were dark, and close, and constant, like the shadow.

*D.H.Lawrence, The Spinner and the Monks

\section{The media frame on history and self-presence}

The acceleration of history

If it were possible, just for an instant, to forget the sufferings and worries of the everyday, if, in other words, it were possible to distance ourselves and somehow see ourselves from outside, I think we should have to agree with Goethe's confession: "I have the great advantage of being born in an age where the great events of the world were on the order of the day, so that I have been an eyewitness of the Seven Years War, of the separation of America from England, and later of the French Revolution, and ultimately of the whole Napoleonic period up to the hero's fall and events that followed it» ${ }^{1}$.

Maybe we can say the same of our times, with greater justification. We live in a remarkable era. As the twentieth century draws to its close, burdened with the tragic memories of two world wars rather than the glory of exploits in space and other demonstrations of "methodological asceticism" and "scientific athleticism", we see the rhythm of historical change becoming faster and more intense. The institutional

$\overline{1}$ J. P. Eckermann, Gespräche mit Goethe, Leipzig, ed. Geiger, 1895. 
and socio-psychological crisis of Eastern Europe, of China, the upheavals in Latin America and the "puzzlements" of the United States, Soviet "perestroika" - all seems to conspire together and force us, rather than direct us, towards the critical review of the makeup of modern societies, their constitution in a material, historically conditioned, rather than formal-juridical sense. This reconsideration originates in and is fueled by new questions pressing against the façade of institutions handed down to us by tradition, and by newly emerging "subjectivities", outside the written laws of established rights. How enticing it is, the claim, or perhaps just the presumption, to confine this torrent of novelties within an eternally valid formula, one both necessary and compelling, timeless and placeless! That is what the arrogance of the experts would like, not to mention the still more unfortunate conceit of the dilettantes.

However, it is legitimate to ask, are we really dealing with novelty? Are we perhaps confusing things, taking for new what is simply different? There is, for example, no doubt that the transitions and transformations currently experienced by certain nations and states - particularly the Soviet Union and the countries of Eastern and Central Europe - are unique, mostly unforeseen and downright surprising. However, the re-discovery of the democratic game, with the multiparty system, election and free discussions, can certainly not be called an historically unheard novelty. Rather, with excitement and gratitude, it makes us think back to Pericles and the Greece of the fifth century BC. It is paradoxical that it should happened "revolutionaries" and innovators to make this discovery of the classical past too. So, it is not a novelty. Rather, it is a return. At all events, it is certainly not the solution, the panacea. It is the beginning of the problems. Democracy is a difficult political regime. The fact that a better one has not been found from Pericles to our own times does not justify passing over its difficulties in silence: no immediate economic enrichment; more difficult, and certainly slower, decisions; often exhausting and inconclusive mediations.

This observation should not appear as the expression of a kind of professorial, didactic spirits. There is nothing pedantic in it. I should just like to point out that when discussing a political regime, an economic system and social policy, the most serious mistakes come from a failure not of good will, but of intelligence. People are almost always more stupid than ill-intentioned. In this field, the most serious errors may come from a seemingly venial fault, and not, as most believe, from the inadequacy of the finances allotted, or inadequate resources of power, but rather from a shortfall in cultural awareness, a lack of clarity of vision regarding the scope and meaning of one's own work. These deficiencies do not merely concern the legislator, too hyperactive not to be also mentally drained and called on to decide before having to hand the demonstrations of the reasonableness of his decisions. Social workers and executives, perhaps immersed in an everyday that is too close and immediate, end up being themselves blinded by it. Something that goes beyond the written juridical rules is 
lacking, something not exhausted in terms of structural reforms and, on the other hand, not to be left exclusively to the romantic inspiration of generic "life worlds", which do not seem to be insured against deplorably decadent results. One needs both the historical perspective and the full critical understanding of what one is doing, and its deep implications.

\section{- Chinese shadows: television and democracy}

At the close of the second millennium, we are living in a rousing historical epoch. As through in a kind of hectic acceleration, almost afraid of missing the appointment with 2000, novelties erupt and explode with impressive timing and swell. In the course of a few weeks, from the summoning of the first "democratic" congress in the Soviet Union - at least in the sense that the voice of the opposition was clearly heard - to the political victory of Solidarnosc in Poland, the birth of parliamentary opposition in Hungary and the dramatic events in Tienanmen Square in Beijing, the ideological and political atlases of the world seem thrown into confusion. It is in these times of rapid, radical changes, prepared from murky sedimentation that the historians of tomorrow will have to decipher, that one needs a photographic image that abruptly synthesizes their meaning: the young student in the square who, in a unique corrida that touches on the grotesque, plays at being the matador to the tank, and, as regards the symbolic charge and with quite different context and meaning, recalls the autonomo firing his revolver in an avenue in Milan during the "years of lead": his face covered by black scarf, gripping the pistol with both hands. That image of the young Chinese student, suddenly both an unlikely bullfighter and an unconscious David versus Goliath, went all round the world. A whole system of values concentrated in one picture! Too late, the Chines leaders censored the TV. The suspension of the satellite service did not stop the record of the facts. The old oligarchy, winning with its tanks, was struck down by photograms.

Does TV, then, at the threshold of 2000, help democracy? A certain degree of prudence is required. Undoubtedly TV informs, and no longer allows power those "private" operations which once defined its essential prerogative and indeed perfected its absolutely discretional nature through mystery. However, the means of mass information does not only inform. At the same time and more insidiously than any crude, traditional censorship, it can deform and dis-inform. The two scholars of social problems who recently examined my The end of conversation (as the American publisher, the Greenwood Press, was pleased to title the translation of La storia e il quotidiano ${ }^{2}$ ), David L. Altheide and Kurt Lang brought forward arguments in its regard that are both complex and convincing ${ }^{3}$. The essence seems to be that TV, like all the

\footnotetext{
${ }^{2}$ F. Ferrarotti, La storia e il quotidiano, Roma-Bari, Laterza, 1986.

${ }^{3}$ D. L. Altheide, The elusive mass media?, and K. Lang, Mass communication and our relation to the present and past, in «Politics, Culture and Society», vol. 2, n. 3, 1989, pp. 414-19.
} 
mass media, informs, and thereby enlarges the public sphere, reveals the secrets of power, proclaims that the king has no clothes, but - beware - TV forces us into a participation that may be spurious, even "domesticated". Not only this, but it also changes the terms of our very "historical awareness", and tends to give rise to new forms of "monopoly of knowledge", no longer so as to inform about reality but actually to "construct reality".

In a recent article by Angelo Panebianco ${ }^{4}$, similar problems seem to take shape in Italy. Panebianco convincingly remarks that «the power of the mass media redefines public space in forms incompatible - generally - with the rules of liberal democracy». After this, the "Corriere della Sera» editorial writer averts his gaze from the unbearable present and lets himself go in a hymn of nostalgia for democracy in grandfather's, those rules were eternal, and a nineteenth century kind of democracy might be an ideal to suggest today, with its suffrage, naturally, limited to elders and notables in today's age of mass communications. Do not misunderstand: Panebianco's liberal-democratic nostalgia is basically much more palatable than the "lessons in democracy" imparted regularly from that paper, with, to say the least, a barefaced shamelessness on the part of those who until quite recently shone for their Stalinist zeal, when they were not teaching young demonstrators how to use Molotov cocktails.

Aside from such understandable nostalgia and dropping our contempt for the brazen, it seems now more than ever necessary, when formulas and myths are collapsing, to effect a leap in political imagination and that of ideals, so as to define the outlines of a democracy worthy of the third millennium. To say, as is too often done, that to desire democracy means to be satisfied, would mean giving in when faced with new realities and their problems even before at least trying to set out a positive solution.

- A united, but not Euro-centric, Europe

In the "Giornale» of 1 October 1989, Indro Montanelli defined it graphically, as is his style, as a "stiletto for progressive». Other intellectuals, writers and literary critics did not lose the chance of putting their masochism on display, almost overstepping the bounds of modesty. I refer to a fat pamphlet by the Englishman Paul Johnson, The Intellectuals ${ }^{5}$. From Jean-Jacques Rousseau to Norman Mailer, in thirteen chapters whose fluid, reserved style makes one forget a certain prolixity, Johnson devalues intellectuals en bloc, uncovering and revealing their vices and holding them up to public scorn.

Let us pass over the weakness inherent in any ad hominem argument. After the acid effect of Johnson's critiques a doubt continues to nag as regards intellectuals. How can one explain that there is no dictatorship or totalitarian state that does not attribute

\footnotetext{
${ }^{4}$ A. Panebianco, Economia e mass media aiutano la democrazia?, "Corriere della Sera», 13 June 1989.

${ }^{5}$ P. Johnson, The Intellectuals, Milan, Longanesi, 1989.
} 
a decisive function to dissident intellectuals, and does not set about swiftly making them harmless? Maybe Johnson is right, and one should trust intellectuals even less than used-car salesmen, but how then do we explain how today a dramatist, Havel, is president of Czechoslovakia?

Perhaps it is true that intellectuals at most are a destructive force, that especially a regime condemned to enthusiasm, as is the rule with a dictatorship, can neither overlook nor deal with as if with an irrelevant, threadbare social group. And yet this phenomenon awaits an explanation which is not a spying through the keyhole. This is confirmed by the most recent development in Central and Eastern Europe. Paul Johnson may have planted his stiletto in the heart of the intellectuals, but this heart is still beating. By common agreement, including Montanelli's, the role of intellectuals in the communist world has been decisive. Whilst the Muscovite empire was flaking away from Lithuania to Poland, Czechoslovakia to Romania, now led by a poet, intellectuals emerged as a determinant force. The vices condemned by Johnson are probably real, not just suspected. But then one must simply conclude that virtue does not hold the monopoly of truth.

On the other hand, it would be serious if the lasting function of intellectuals in the recent transformation of central and Eastern Europe had arrived at the right moment to prop up the Euro-centric conception of history. Too many newspapers and some reviews in recent months have rather precipitately set to work to persuade us that "history has resumed its course". Like diligent, if ill-informed, station-masters, newspapers and reviews have issued timetables and routs which give the impression of being emergency medical bulletins. Europe, lately in coma, has begun to show signs of life. The patient is waking up. The European train is starting off. It is like the Congress of Vienna in 1815, as if forty years of events could be calmly put in parentheses, as if history should wait for their precious signals to stop and start. To register and also acclaim the function of intellectuals in the recent events which have changed the face of Europe should not be confused with a kind of consecration of the ancient primacy of Europe. This primacy is nothing to be proud of. It drips with blood and tears. And yet, when today we go back to talking of a "common European house", and a Europe united from the Atlantic to Urals, one remarks on a suspect emphasis, which even the triumphant statements of john Paul II do not seem proof against. One can understand the legitimate satisfaction of this polish patriot, smiled upon most recently not only by joy at Warsaw liberated but the unexpected Canossa of Gorbachev's visit to the Vatican. However, the fall of "real socialism" should not make one forget the undeniable limitations of Western democratic regimes, the social unease that erodes their basis, the moral flatness of societies in which, along with ideologies, hope too is dead. 
If history, as it is said, has resumed its course, it is as well to ask oneself, and be certain about, what history we are dealing with. Europe has been a colonial power which has destroyed whole peoples and cultures, and paid dearly in first person for the atrocity of genocide. There is no more room for any European primacy. If history has started moving again, it is to be hoped that Euro-centric history has been forever switched into a siding. We cannot escape history. Outside history there is nothing that corresponds to the collective efforts of human beings. We should not confuse the end of ideologies with the end of ideals. We must rediscover the social function of utopia, and patiently construct a neo-historicism from beneath, where elite history is transformed and reborn as the history of all.

\section{Why people like Italy}

\section{- How a democratic ruling class dies}

Reflection on Italy today cannot overlook yesterday's roots. One necessarily inquiries into a people with many lives, seeking a meaning in the complex traces of thirty centuries of history. However, the contemporary is a help: it poses seemingly marginal questions which in fact reach the heart of the problem. The mystery of the powerful attraction still exercised by Italy on foreigners remains. It cannot be merely the taste for the exotic, which in any case air travel can appease more readily and more appetizingly than in any other era. Nor can one relate it to the resonances of certain books at the origins of high level elite tourism, especially in the belle époque, like John Ruskin's Stones of Venice or Morning in Florence. Their contribution to the collective imaginary of the countries of Northern Europe and North America is incontestable, but their power has been evaporating during two disastrous world wars. One poses the question again, therefore: wherever does Italy's attraction come from? From its great, extraordinary artistic heritage, from Rome being the center, if you prefer the headquarters, of one of the five great universal religions? Or, again, from subtler, even perverse motives: from the disorder, from the general sense of culpability which is self-absolved? But then, how can a whole country "outside the law" give joie de vivre?

It may be that Italy's fascination today comes from an existential, structural, and unresolved, tension. Every so often it happens that Italians feel and believe themselves to be, modern, indeed, post-modern. On the rich ruins of their history, they seem at times to forget their deep archaic essence. In a generation or little more - between 1955 and 1985 - they have completed their "industrial revolution". They have turned their backs on the estates, the fields, the smallholdings. They are modernized, or, more exactly, urbanized. They have left the country for the city. Then they have had starts, almost regrets, fits of memory, like someone who returns hurriedly, rather absentmindedly, the way he has come, because he has left the light burning in the old house. Modern: post-modern: post-post-modern. Nothing of that. 
The argument of this book is that Italy today is neither modern nor post-modern. Italy is in the balance between yesterday's world, the world of acceptance of the past as legitimation of the present and of any possible future, and the world dominated by the logic of productive and distributive rationality and the impersonal forces of the markets. Italy is in the balance between the civilization of touching and feeling and that of buying and selling: between a society determined by primary face-toface relations, and one held together by bureaucratic mediation set up by law and embodied in formally codified institutions.

It is therefore true that Italy is a society in transition. This phrase, so often repeated, has been reduced to a banal commonplace, aside from the risk that once again the object to be explained (transition) is unconcernedly employed as criterion of explanation. At any rate, there is no doubt that Italy is a society in transition. That is true, moreover, of any society. Even the most static society - that of Karl Wittvogel's "oriental despotism", for example -, is in transition, if for no other reason but the continual birth and death of the people who make it up. A more rigorous: idea seems that Italy is suspended, so to speak, or, as mentioned above, is in the balance between the peasant civilization, now abandoned, and industrial civilization struggling to be born and make itself heard. Italy today is in a hybrid situation: no longer peasant, not yet industrial, a docile, even consenting and complacent victim of an identity crisis which, whilst its traditional referents cloud over, infinitely enriches its choices, its possible transformations - perhaps the opportunistic disguises and ideals, secondhand and reduced to phantasms. In this sense, Italy today illustrates and confirms a basic truth as well: lack of means but no lack of ideas of internal renewal.

However, one must make it clear, that Italy certainly has its feet in industrial society, and also post-industrial society, if by that we mean a society where now the services of information and distribution prevail over those purely and directly concerned with production. Recently there has been a long, learned discussion of whether Italy has moved ahead of England as an industrial country. England is in fifth place among the great world industrial economies. It is even argued that Italy is about to take France's place, the sister nation, friend and enemy, arriving in fourth place behind the United States, Japan and Germany. But industrial culture, the internal disposition towards responsibility for the task whereby the individual does what he has to independently of the eye of the boss, of fear of punishment or desire for reward - that is still in the future. Here the "fear of the lord" triumphs. In Italy one still behaves, on average, on the basis of the vision of canons which combine weary evangelical preachings with little everyday tricks: Principium sapientiae timor domini. Everything is allowed as long as you get away with it. 


\section{- The personal moment and the bella figura}

I do not want at this point to fall into the trap of a discussion like Giuseppe Prezzolini's, resting on the schematic counter-posing of ingenuous Italians and super-sly Italians. It is clear that discussion of the national character of Italians exposes itself to many objections. The very notion of national character or temperament has been often, rightly, criticized, as insufficiently identifiable, defenseless as regards age-old prejudices, superficial, and fleeting. All quite true, and must make certain statements possible. Allowing for considerable margins of error, one way that the Italian does not have a strong sense of public interest, does not easily obey the established rules of society, from those involving traffic to tax returns, the rules for defense of the countryside, and those for street s of Geneva and those of Rome is rather depressing for the Romans. There is no doubt that political terrorism involves all the industrially advanced nations today, but it is hard to find in these countries phenomena of organized crime comparable to the Sicilian mafia, the Neapolitan camorra and the Calabrian 'ndrangheta. Aside from the phenomenon itself, the strictly local root, the structure, the code - I was about to say the regional bouquet -, are interesting.

In no technically advanced country does one find - as on the contrary happens in Italykidnappings for extortion. Here is a crime that is also a lesson in cultural anthropology: a country that has discovered - and how! - the value of money, a highly financially refined country, and at the same time a culture where a family is still ready to go into debt for the next twenty years to save a relative, and the magistracy accepts a suspension of the law. More precisely, it is a culture in which a very limited confidence is conceded, bearing in mind that the state is unable effectively to protect its citizens and for that very reason faces certain de-legitimation.

Thus, when after two years a kidnapping ends well, and the victim comes home, as happened to the young Cesare Casella of Pavia (end of January 1990), the whole city celebrates, there are processions of cars through the streets, an explosion of collective joy which is certainly genuine, but misplaced. We are in Pavia, not in Naples or in Palermo. The real Italian tragedy is that a serious problem, one unacceptable for civilized country today, becomes a "happening" in Italy. Theatricality conquers everything. Rather than moral philosophers or social analysts, it may be that once again a great writer can help us understand this case of anti-modernity: «natural expression seems to (the Italians) too easy to find, and in their eyes lacks that ingredient of pleasure deriving from the sentiment of difficulty overcome» ${ }^{6}$.

Seeking the "Italian ideology" in the works of Italian intellectuals seems to me time wasted. What is, in fact, if it exists, the Italian ideology? The average mentality, that is? 
What, like a submarine, crosses the generations untouched, emerging unexpectedly, at time, during dire crises, to dive afterward once more, and disappear?

A crisis, for example, like that of 8 September 1943, when general Badoglio signed the armistice, but with characteristic ambiguity asserted that "the war goes on", has emblematic value. Everyone, or almost everyone, as one says, "read between the lines". Aside from the official pronouncements, the key phrase that rang out then, dictated by no one but which, powerful and impersonal, arose from the deep, was simple and final: "Everyone go home". Home, the family, one's nearest and dearest, one's own "particular". In today's Italians it seems to me there is more Guicciardini and Leon Battista Alberti, than Machiavelli. In September 1943 everything around was crumbling. Only the ancestral home, the village, the family remained standing, that hard kernel that the family micro-society represents in Italian anarchy - the supreme source of psychological security and moral obligation.

It is not, therefore, surprising that the personal moment prevails in the Italian; the external bella figura, the projection of the feeling of a group not yet of autonomous individuals, but of famuli, industrious and true. In a nutshell, the "Italian ideology" the median behavior and mentality. can be wholly expressed in one phrase: ethical problems are reduced to aesthetic attitudes; decision to gesture; opposition to bel canto ant to consideration or conspiracy of the corridor. Over the act of conscience, which presupposes the individual, there prevails the plot, the dominion of the group or clique or gang. "The Sicilians (we may say, "the Italians") simply don't have any subjective idea of themselves, or any souls. Except, of course, that funny little alter ego of a soul which can be prayed out of purgatory into paradise, and is just as objective as possible " ${ }^{7}$. Taste for, cult of, the knifing, the fine gesture, the mot, the murderous remark. Hyperbole, exaggeration, is at home here. Words instead of things, as if the word, in a sacral way, operated ex opere operato. No check, no concern for practical realization, for its modalities, its foreseen and unforeseen consequences. Little interest in maintenance. As if what exists would exist for ever: a displaced sense of eternity. Hence arises the conservative anarchism of the Italians, their irresponsible and immobile "revolutionism". A few, shining exceptions occur: men like Carlo Cattaneo and Piero Gobetti.

We shall have to resolve to return to the great, forgotten lesson of Adriano Olivetti: it is not enough to desire and preach reforms sub specie ideologica, making a display of doctrinaire attitudes as nosy as it is ineffective. One must humbly study the specific technique of reforms, evaluate their possibilities and exploit their points of agreement.

${ }^{7}$ D. H. Lawrence, Selected Essays, London, Penguin, 1950, p. 282. 


\section{- The family is strong because society is weak}

In this perspective a seeming anomaly is illuminated. The Italian family is strong, despite abortion and divorce, precisely because society is weak, and functions badly or not at all. The family is the hidden shock-absorber of the inadequacies and contradictions of society as a whole. Regarding the median behavior of Italians, it would be legitimate to speak of "amoral familialism" if the public, social structures functioned averagely at a level of acceptable efficiency. But this is not the case. Any Italian knows it. He thus saves even more than the Japanese, since he cannot count in social security in emergency, such as the unexpected illness of a family member, especially if it involves surgery. He cultivates a network of personal friendships because he cannot trust the impersonal norms of the law. In short, inter-personal relations in Italy are rich, richer and more vital than elsewhere, because the service from institutions is impoverished, slow, intermittent and untrustworthy. It is not surprising that such a society should penalize the young, who, just being young, have limited network of primary relationships available to them.

The 1989, December, Censis Report assured us that Italians today are rich and unhappy. The old stereotype of the Italian poor but beautiful, and happy, is simply inverted, however, there is in the conclusion of this report an unresolved aspect, a question still to be tackled, which probably pints to a defect in interpretation. Given the wealth, where does the unhappiness come from? Perhaps because wealth is not sufficient to guard against the unknown elements in the future in a society which basically does not exist, or is "foreign country", and where accumulation must be pursued still with all available means. Or else unhappiness should be seen as the fear of losing wealth. It is feared that the condition of wealth - an unheard-of condition for the average Italian will not last long, finishing up dissolving like a dream at dawn.

Perhaps these general psychological, structural questions should leave us not so surprised that success is bad for the Italian. It draws out all the arrogance of successful cunning, the bad taste of the parvenu, and the jolly arrogance of someone who has got off scot-free. Italians are wonderful in adversity: their genius for survival, which in their long history has always miraculously helped them, and their existential ability to resist, and for human compassion then are at their height. This capacity for suffering and solidarity also towards strangers, and the compassion of Italians were demonstrated during the darkest years of persecution of the Jews in Italy.

It is this vitality that wins over foreigners, the active resistance of this choir of soloists waiting for the Imprimatur (as I once felt it right to describe them) - and which moreover invariably drew words of admiration from Stendhal. It seemed to Beyle, Milanese by

\footnotetext{
${ }^{8}$ See the instructive contribution by S. Zuccotti, L'olocausto in Italia, Milan, Mondadori, 1988; but the basic work in the Holocaust in its full extent is still that by L. Poliakov, Il nazismo e lo sterminio degli Ebrei, Turin, Einaudi, 1955.
} 
adoption, that the human creature in Italy was more full-blooded and vigorous than in France. What is Paris could be the occasion for endless drawing-room discussions - he thought - was rapidly settled in Italy with a knife-thrust. At all events, it is incredible that we must still read his Chroniques italiennes in order to understand the concept of power still prevalent in Italy, from the anthropological viewpoint and that of everyday behavior; its extreme personalization - unconscious, one would think - and its habitual violence, in the sense of the law distorted or modified at will. Bear in mind his warning to the reader: "The passionate manner of feeling peculiar to the Italians around 1559 demanded actions, not words. Thus there will be little dialogue in the story that follows. This is a disadvantage for my translation, since we are used to the long conversations of our characters, for whom a conversation is a battle... Rome, though without a menacing army, was the capital of the world. Paris, in 1559, was a city of somewhat refined barbarians» ${ }^{9}$.

En passant, Stendhal made soundings beneath the skin of the Italian character which are unbelievably precise.

"The heroic element in these stories moves the artistic fibre still alive in the plebs and, on the other hand, it is so sated with the official praise bestowed on certain persons that what is not official in this genre goes straight to its heart. One must be aware that the common people in Italy suffer from some things the foreign traveler would never notice, even if he stayed in the country ten years. For example, fifteen years ago... it was not infrequently the case that bandits punished the extortions of the governors of little cities through their exploits. These governors, absolute magistrates whose stipends did not exceed eight scudi a month, naturally obey the family locally most considerable, and this, through this most simple of means, oppresses its enemies. If the brigands did not always manage to punish those little tyrannical governors, at least they took no notice of them and challenged them; and this is of no small account in the eye of an intelligent people like the Italians. A satirical sonnet consoles them for all their ills, and an offence is never forgotten. This is another radical difference between the Italian and the Frenchman ${ }^{10}$.

Stendhal's final comment is instructive. "Such a state of civilization certainly offends morality; today, we have the duel, boredom, judges that cannot be bought. But those sixteenth century customs were admirably suited to produce men worthy of the name» ${ }^{11}$.

\footnotetext{
${ }^{9}$ H. B. Stendhal, Cronache italiane, Florence, Sansoni, 1966, p.11.

${ }^{10}$ Ibid, p.134-7.

11 Ibid, p.137-8.
} 
We find a similar tone returning in Hans Magnus Enzensberger today ${ }^{12}$. Contemporary Italy impresses him - positively - with its chaos and ability to live in it, indeed, to prosper in endemic disorder, with nuisance strikes and demonstrations, tax evasion and the submerged economy. Enzensberger is fascinated by the Italians' cynicism, their salutary lack of respect for the state, too recent in contrast to such an ancient society. Perhaps he would agree with the maxim whereby governing the Italians is not difficult - it's useless. They have seen so much, too much. Governed from time to time by the Spanish, French and Austrians, politically unified only in 1860, they still see in the national state something distant, if not extraneous or artificial. They are naturally supranational. And it is here that they might perhaps, unwillingly and without believing in it too much, offer a lesson to tomorrow's Europe.

\section{- Italian imagination as scarce raw material}

Europe could soon have need of Italian imagination, of the cheerful skepticism, economic invention and political irreverence of the Italians. To avoid the grey, inglorious collapse into the mediocrity of bureaucratic quagmire where French vanity and haughtiness, German greyness, the dull shopkeepers' spirit of the Benelux are added together, the Italians' dynamism and even irresponsibility seem an essential ingredient. A new spectre is haunting Europe today. Not that of communism Marx and Engels spoke of in the Manifesto, with the terseness and touch of brashness typical of unemployed professors, when they published it, in Brussels, in 1848. Nor does it involve the new difficulties opening up at the end of 1989 with the fall of the communist regimes of Eastern Europe. This fall, dutifully publicized by the TV, makes possible and realizable the idea of a Europe from the Atlantic to the Urals, but neither the protagonists nor the commentators seem to notice that the rediscovery is not the solution, but rather the beginning of the problems.

Soon Poland and all Central-Eastern Europe will experience the rigours of the open economy, there will be mass protests, strikes and disorders.

The spectre of an ultimately united Western Europe, at least from 1993, is a different one. It is called Brussels. One should go back and read what Charles Baudelaire wrote about Belgium and Brussels. Poets often have a sharper eye than politicians, see more deeply than sociologists, and evaluate the weight of some structures and behavior better than the economists. One does not live only by good cloth or good chocolate. The astuteness and shopkeepers' meanness as way of like are not enough to create Europe. When the countries of Europe have to conform to common laws, supranational ones, it is basic that these laws do not aim too low, that Europe should not be reduced to the back-shop of Bouvard and Pécuchet. It is useless for social analysts to be concerned with consoling future European citizen by showing that the

${ }^{12}$ See Ach Europa Europa, Milan, Garzanti, 1989. 
price of progress is unfortunately a whole life spent shut up in the sealed shell of institutions - in other words, that one must be accustomed to live, or trudge along and survive, within a maze of walls, visible and invisible, imposed by the bureaucracy to confront the changing needs of an ever more complex supranational society.

No one would dream of denying the need for bureaucratic regulations, which is their very character of impersonality and through their mechanism guarantee, at least theoretically, egalitarian treatment for all citizens. It is well known, and the sociology of organization has conclusively demonstrated it, that bureaucracies tend towards a "displacement of ends". That is, they tend to change from being instruments to becoming goals for social action. They are a necessary skeleton for modern states, made ever more necessary by the social policies and the various subsidies that states have assumed as an essential function, but they tend primarily to assist themselves. One might say that bureaucracy is generally a good shepherd whose benevolence decreases when its own institutional existence is at stake and under attack. It has a remarkable capacity for survival. In the name of institutional continuity it survives and adapts to all regimes. It is transideological. It expresses well the deep, submerged tendency that has linked all the processes of modernization, independently of ethico-ideological legitimations and justification, from capitalism to the various "real" socialisms. It synthesizes in itself the irresistible isomorphic tendency which marks all those countries that have decided to follow the path of modernization and industrialization, from the beginnings of the "industrial revolution" in the mid-seventeenth century to today - the threshold of the third millennium.

We have arrived at the paradox. Here, the Italians enjoy the dubious advantage of their evident, historical deficiency. To use Veblen's formula, they must certainly not suffer the "penalty of taking the lead". Their public administration is one of the most backward. It retains the typical signs of a legalistic-formal bureaucratic administration, possibly suited to a closed, peasant and artisan society, where the user is seen not as citizen-customer but as subject to be overtaxed and squeezed. It is not a functional bureaucracy, able to anticipate problems before they explode, on the basis of mediumrange forecasts. It can intervene, when it does so, only after the fact, once the disaster has occurred. This has a very high social price, perhaps an incalculable one. But it also has a positive aspect. Citizens cannot expect much from the state bureaucracy. They cannot cling to it like the suckling to the breast. In fact, they can expect almost nothing from it. Therefore, they must look after themselves, save, lay up the means to face emergencies, personal and family; cultivate friendships, prepare networks of informal protection which a relatively unprotected and absentee society makes necessary. The provisional thus becomes definitive. The expedient becomes a basic means of subsistence and survival. 
Italians thus emerge as the least disciplined Europeans as regards the state. Tomorrow, they will probably remain in a united Europe, also the most enterprising Europeans, proof against community planning and laws. But will this innate indiscipline be enough to save them? Will they be able to accompany the other European partners, at the same pace, the same regularity regarding average income, constant productivity, and ability to resist?

\section{Industrialization without an industrial culture}

- An error in perspective: production versus services

Let us take a step backwards, running back over the years from 1945 to the present. Reconstruction in Italy took place from 1945 and 1955. It began with the re-joining of the North to the rest of the peninsula, and with the coming to power of the Parri government. Following a seemingly political criterion, but really one inherent to the development of Italian social structure, one can subdivide this period into three: 1945-48, 1948-50, and 1950-5.

The first attempt at reconstruction took place in 1945-8 through the Marshall Plan. The Americans undertook a massive financial operation on a European scale, which was also economic, technical-industrial and political. This intervention unleashed a headon clash between the moderate parties and the left opposition. The anti-fascist parties were united until the proclamation of the Constitution and the declaration of the National Committee of Liberation (CNL), and the task of reconstruction, until then one common to communists and liberals inclusive, became the ground for sharp political divisions. The communists especially, and the "fusionist" socialists, that is, the "socialcommunists" as they were then called, opposed the Marshall Plan seen as a means of American capitalist oppression. But reconstruction had to be undertaken, and if the left was not ready to produce strategies and tactics, and thus in practice excluded itself, reconstruction would be accomplished without it. The concrete, practical need for re-construction was taken on itself by Christian Democracy, along with its lesser allies (liberals, republicans and the PSLI). The results seen in the electoral victory of 18 April 1946, which brought the Christian Democrats to an absolute majority (48,9\%). The second phase of the re-construction began. The trade unions (CGIL), especially through the efforts and leadership of Giuseppe Di Vittorio and his enlightened realism, realized that re-construction carried forward without the workers, would inevitably be built against them. Hence, the famous "plan for labour" was enunciated by Di Vittorio at the Genoa congress of the CGIL in November 1948, wherein the Italian working class, though with ideological reservations expresses at the time forcefully by Vittorio Foa, accepted the Marshall Plan, and began its active collaboration with the re-construction of the country. 
In 1948 the second phase of re-construction began, as a national task on the socioeconomic level, whilst paradoxically the parties of the left were forced into opposition. It is hardly necessary to mention that at the time of the assassination attempt on Togliatti by Pallante, it was especially the cadres of the CGIL who exerted themselves against the dangers of popular insurrection and in favor of pacification. This period of relative social peace lasted till 1950, when, with the acceptance of the Atlantic Pact, the "political" consequences of the economic-technical and socio-industrial aspects of the Marshall Plan became clear and operational.

With the tormented acceptance of the Atlantic Alliance and Italy's official entry to the Atlantic sphere of hegemony, dominated by the US, there began the third phase of reconstruction, when the premises were established regarding the promotion of mass production industries, and of the insertion of the Italian economy into the European and world framework by way of the elimination of all protectionist and customs barriers of self-sufficient and fascist origin, thanks especially to Ugo La Malfa.

By 1955, Italian politics was increasingly internationalized, and Italy prepared, through the Treaty of Rome, to become one of the key members of the future European Community, along with France and Germany. One may say, generally, that Italian reconstruction was at once a great historical undertaking for a traditional country such as Italy, and a lost opportunity. Indeed, in the course of a generation or slightly more, Italy was to be transformed into a urban-industrial society from a rural and artisan economy - a transition that required a little under two centuries in England. At the same time, in this massive structural and socio-cultural transformation, the Italian ruling classes showed they had not learned much from the tragic experiences of the countries that had preceded Italy on the road to modernization. The transformation was to be carried out under the banner of unfettered social Darwinism, ill-concealed by the ideology of free enterprise and the cult of private initiative. The epic of internal migration from South to North and East to West was to be carried through in the wild state, without excessive concern for the social infrastructures essential for any civil country. Funds were allotted to the South, but in a "clientelistic" perspective, not a productive one, thereby perpetuating a tradition of capillary corruption.

The overall contradictions of the system were to be aggravated rather than resolved. Italy was ultimately to come out of re-construction as a country at once Bourbon and electronic. However, no one can honestly deny that the re-construction begun in the years 1945 to 1955 with its patches of light and shade made it possible for Italy to take an important position among the six most industrialized countries into the modern world. What was once called the "garden of Europe" now exports more machine tools than Sicilian oranges. 
The old ruling class had aimed exclusively and, when required, harshly, at production, and the quantitative and qualitative increase of productive capacity. It neglected and put on one side - as an extra which would providentially arrive by itself - the basic social infrastructures (houses, schools, hospitals).

The years from 1960 to 1980 , with their creeping social conflicts, the general protest of 1968 and later the "years of lead", peaking in the kidnapping and killing of Aldo Moro, were to be entrusted with clarifying the fatal extent of this error of perspective such a natural one, in any event, for a ruling class always authoritarian, paternalistic and manipulative. But let us take things in order. In the complicated undergrowth of empirical data, let us try to establish a plausible time-line that covers the three decades between the late 1950s and the beginning of the ' 90 s.

The years between 1954 and 1958 are marked by three phenomena: a) an accelerated economic transformation, b) the development of the postwar political framework, c) general cultural modernization.

We are dealing with phenomena determined by their own specific logic. No critical filter seems able to grade them and make their development relatively coherent. The scenario is typical of social Darwinism and untamed growth. The political ruling class, which in a democratic regime should mediate them, seemed lost in its internal power games. In the background there was the peasant exodus from the South, providing Italian writers with human material of the first water for remarkable displays of stylistic bravura, but also demonstrating primarily the persistence of an unresolved "Southern question", with subsequent processes of massive urbanization in the re-industrialized cities of the North, joined on to a rising birth-rate.

These are the years preceding and accompanying the economic boom. In the absence of a policy of efficient planning, the phenomenon rested on the competition and superimposition of different factors. The exodus from the South and the countryside real biblical migrations - supplied labour at low cost to the North's firms, which were then involved in their take-off into international markets. The scenario is the usual one when there is a question of creating the financial accumulation required for the take-off of large industry in an international scale: low wages, rigid factory discipline, and constricted private consumption. Only at the start of the '60s was there to be a "mobilization of consumption", with an enlargement of internal demand and the spread of a consumer culture.

The post-war political picture was also changing. Christian Democratic hegemony, based on centrist governments, was crumbling. 1954 may be considered a symbolic year in this regard. Alcide De Gasperi died - the man of 18 April 1948. Amintore Fanfani, the rising leader of the party, worked to free Christian Democracy from a double dependence, to the ecclesiastical hierarchy, and that linked to the notables. 
The key objective of Fanfani's strategy was the untrammeled occupation of the great state institutions, with the creation of a politico-administrative bureaucracy, provided with its own financial resources and politically protected, and with autonomous channels of consensus.

The international setting, despite the cold war, was relatively reassuring. Indeed, in 1954 the Italo-Jugoslav agreement closed the last of the wounds opened by the war. Attention was directed towards the internal situation, the decline of De Gasperi's centrism had begun.

In the phase of transition now developing, big industry played its hand forcefully. Valetta Fiat headed an anti-union offensive in every field. The aim was to rob the CGIL of the responsibility for central contract negotiations, by promoting a factorylevel devolution where autonomous unionism could find its space. The 1955 elections for the renewal of Fiat internal commissions were an important stage in employer strategy. The CGIL suffered an historic defeat, the Valletta order was re-established and became the premiss for company expansion in an atmosphere of controls which spilled over into episodes of repression. However, the defeat prepared the way for a phase of intense strategic maturation which was to produce important results in the following decade and was to stimulate the coming of a union culture and leadership more alert to the complex dynamics od industrialization and of social integration in an urban context ${ }^{13}$.

In 1956 signs of a political autonomy appeared which demonstrated the progressive coordination of worker identity no longer totally subordinate to traditional subcultural environments. The CISL began to differentiate itself from Christian Democrat management of public bodies, by inspiring some negotiations in state enterprises. Di Vittorio's CGIL refused to back the repression in Hungary, which found excuses in the ranks of Togliatti's $\mathrm{PCl}$.

However, the emergence of identities and contradictions typical of industrial culture did not conceal the main social data of the period. Italian political and socio-cultural life was still hegemonized by the dominant ideological subcultures, which indeed experienced new forms of insertion in the productive base. The boom might be the child of large-scale industrialization, but also of the growing vitality of the artisan or semi-industrial enterprise flourishing in the geographical heart of the dominant subcultures, the catholic Veneto and "red" Emilia. Umbria and the Marche were to be added to these.

\footnotetext{
${ }^{13}$ The victory of spurious company organization, instead of negotiation realistically based on specific company situations was undoubtedly assisted by the ideological "schematism" of the CGIL, as Di Vittorio himself in time recognized: cf. my Sindacato, industria, società, Turin, UTET, 1970. See my La protesta operaia, Milan, comunità, 1955, for a vigorous critical challenge to ideologically doctrinaire attitudes; the book attracted harsh reprimands: cf. for example P. Spiano, La protesta operaia, "L'Unità», 2 November 1955; F. Onofri, Il Maometto di Olivetti, «ll contemporaneo», 17 September 1955.
} 
The liveliness characterizing the world of associations - think of the ACLI or the youth and university left - was based on the dialectic with the mass parties, to which it was to supply the future leading cadres.

It was war between the two mass parties, DC and $\mathrm{PCl}$. Halfway through the decade, Fanfani had worked out the theory of the "breakthrough to the left", starting a distant dialogue with the PSI for anti-communist purposes. The post-Stalinist period had not allayed the claim of communist "diversity". Nenni and Saragat met at Pralognan in 1956, feeding rumours and expectations of an autonomous re-composition of the socialist movement, which were disappointed in the short-term, whilst forming part of the puzzle preceding the choice of the center-left, outlined in the Venice Congress of 1957. 1957 was also the year of the treaty of Rome, which inspired the European common market. For the Italian ruling class this was an instrument of international legitimation, and a potential way out of a national role closely circumscribed and subaltern in the post-war years.

The political elections of 1958 gave the DC over $42 \%$ of the vote, but the "breakthrough" did not succeed, and the $\mathrm{PCl}$, thanks to a trend which was to sustain a whole current of political science, was also strengthened, whilst socialist growth was limited, and the traditional right clearly declined. The electoral result had the effect of accelerating the debate which was to lead to the outline of the future center-left. This was a laborious process, invading a new session for the catholic world as well: 1958 was the year of Pius XII's death and the succession of Cardinal Roncalli, John XXIII.

- The first step into the boom

Obviously, economic changes and political tensions do not account for the whole outline of the period. However, they are the referent and mould for the modifications which involved customs, culture, and models for behavior. 1954, for example, was not only the year which marked an intellectual watershed between two periods of government. Perhaps primarily, it was the year state TV transmissions began, something destined to characterize an era, even in that climate of stifling institutional control and, at times, sanctimonious censorship to which the programming was subjected from the start.

It was also the year of the first dramatic scandal in government which unsettled the Christian Democrat political group, tearing aside the veil of traditional morality in which it cloaked its public image the "Montesi case". The leaden cultural atmosphere of the immediate post-war period was, moreover, also cracked open by more innocent displays of customs which revealed the emergence of exotic-consumerist fads and fashions, alongside archaic cultural survivals. Those were the days of the frantic (and costly) search for the miracle-working "Chinese mushroom"... 
A major collective fact (TV), a scandal of the regime, a mass-mania: three instances of unequal significance, but meaningful in drawing the outline of an incipient cultural transition. It was a process in which the intellectual vanguard was not external - a vanguard emerging laboriously from the greyness of the fascist period and from post-fascism itself, and which launched a challenge, still largely by infiltration, to the traditional models and their idealistic setting.

This is the period of the hardest, most original gestation of Pasolini's fiction and poetry, which gave the world of metropolitan uprootedness citizenship and expression (Ragazzi di vita, 1955 and four years later Una vita violenta). Fellini's La strada offered a cinematic observation laden with disenchantment, of loneliness and hope. Neorealism evolved towards more complex themes reflecting the condition of immigrants and the new metropolitan marginality. Dino Risi asserted himself in the preludes to what was to be Italian-style drama (Poveri ma belli, 1956).

In 1955 the Fiat 600, produced in its great "normalized" works, launched in an advertising campaign symbolizing a collective social promotion by way of consumerism, commenced a period of accelerated car ownership. One could glimpse the signs of a first wave of the mobilization of consumption which was to mark the subsequent historical phase. State TV invented the first popular spectaculars, with Mike Buongiorno and his Lascia o raddoppia? In 1956, for the first time, 10 million foreign tourist came to Italy, an enormous phenomenon of custom from which moreover the economic contribution to Italian recovery was gathered.

300 workers died in a mine at Marcinelle, in Belgium. Many were Italians. It was the other face of the proclaimed "miracle". A massive program of various public works was undertaken, intended to accompany (and assist) Italian car-ownership. In 1956 the Autostrada del Sole was begun, whereas the public transport system often remained at a level of underdevelopment. The sinking of the "Andrea Doria" struck the collective imagination: radio and TV entrenched themselves through their capacity for advocacy and influence.

Between 1956 and 1958, the trends became clear: the picture was richer, and the paths of modernization stood out. The impulse to consume which was increasingly assisted in this phase by the entrepreneurial and economic policy levels, was reinforced. The launching of the Fiat 500, the mini-popular "truly for all" runabout symbolized this. The crisis of the regime's political "equilibria", as always in such cases, took place in a swell of dramatic courtroom events (the Giuffré case, first of a series of untroubled "God's banker" cases, was emblematic). The Merlin law, enforcing the closing of licensed brothels, divided public opinion in a dispute regarding Italian common sense - extremely revealing from the viewpoint of national anthropology. 
However, the trend to a partial de-provincialization of artistic-cultural phenomena was not countered. In 1956 Moravia and Carocci founded «Nuovi Argomenti», which was to become a favorite place for the "intellectual contradiction" of the left. The same year Milan hosted an exceptional jazz festival for the first time in Italy. The year after, in New York, Venturi was to present a successful exhibition devoted to the avant-garde Italian painters. Again, in 1957 Gadda published Quer pasticciaccio brutto di via Merulana, with its charge of linguistic invention and literary transgression. 1958 was the year of the re-discovery of The Leopard, marking a great publishing project and implying a mass cultural option, still in embryo but significant. This was also the year of Modugno's revolution in light music, with its success at San Remo, symptomatic of a break functioning now also at the level of popular taste, whilst with Contracronache we witnessed an alternative use of song and the language of the masses.

While the previous years had permitted material accumulation of resources destined to the accelerated economic expansion, those between 1959 and 1964 were those of the expectation of reform. As we have seen, the first expansionist wave in the postwar Italian economy had set off the crisis in the system of government. Though confusedly, there made progress among the principal forces themselves an awareness of the immense human and social costs of accelerated industrialization, and therewith the need for rationalization which would prevent large-scale degenerative effects and, indirectly, a radical de-legitimation of the system of power built up, with various modifications, in the fifteen years since 1945 .

It was in the context of this hectic and increasingly uncontrollable economic expansion that the development of the political framework should be situated, leading to the first experiences of the center-left. This expansion was already fully visible in the second half of the " $50 \mathrm{~s}$, but was not translated into civil and social "development" comparable to the rates of growth indicated in the economic indexes. The exodus from the - mainly Southern - countryside towards the Northern industrial cities now meant the depopulation of whole areas of the country. Nor was the socialization of these Southern rural masses within the urban-industrial system an easy task. In some cases, the increase in births in the absence of essential social services and civil structures caused Latin-American-style aspects of urbanization. Tertiary cities like Rome also swelled, producing processes of spurious modernization that were chaotic and devastating. The urban ghettos of immigration sprang up, whilst a massive rate of population increase continued notwithstanding emigration. The 1961 census showed this to be of such proportions and with such acute potential effects that it enforced urgent strategic alternatives on the uncontrolled model of expansion which determined the economic system and that of social relations.

The development, or better, the expansion, of the economy was in fact also causing mobilization of social forces, which is the politically critical side of the 
socio-demographic transformation. The idea of the "opening to the left" matured under the awareness of this visible trend, to which the forces of government, and in particular the Christian Democrats, responded by indiscriminately increasing public economic investment in the South. This was a strategy functional for the creation and occupation of new centers of power for the ruling political personnel, but which was not foreign to a culture of efficiency linked to generally "Southernist" inspiration. It was political strategy vocation, pressing for the elimination of centrist immobility, and for a model of differentiated and "technocratically" planned development. The expectations of reform which accompanied the first steps of the new political framework was thus the feature that politically characterized this phase. Naturally, too, it was to be the yardstick for the disappointment which followed. It should also be said that this period saw a relative rebirth of economic and social research itself, often inspired by a return to American functionalist themes, or to catholic solidarity. The philosophy of "planning", with some ideological corollaries which herald the unpropitious lamentations for the end of ideology, was the central line of the centerleft project. However, it really involved a philosophy of self-suggestion influenced by the illusion of being able to manage the socio-economic situation in process of transformation, without seriously upsetting the political balances. Paradoxically, this was done by theorizing a broad deployment of public investment, in the presence of a left opposition diffused in capillary fashion geographically and hub-culturally. The mediating, institutional drift of the center-left (as Tamburrano put it, from the emphasis on contents to the falling-back in alliances), was to be the result - among other things - of this illusion and unsolved contradictions. Italy, meanwhile, experienced phenomena of impressive fluidity in the course of a decade or little more. 11 million citizen changed homes, moving from the country to the cities, from South to North, from fields to factories.

The traditional fracture of development-under-development of such a picture was redefined, changed shape and social subjects, but was not re-composed. (The change in social subjectivities, for example, involved a shifting of contractual power between factory workers and "decentralized" workers which was to influence the political composition of the class). The policy of torrential state investment was to produce "cathedrals in the desert" and cultural rooting out in the South, creating an open season for direct confrontation between social groups. This was to create the first embryonic aspects of conflictual politicization in the Northern industrial centers. Consumerist mobilization, with its implication of passive economic citizenship, became in the meantime the central element of socio-economic and cultural transition. The passage of time was to bring out its objective surrogate function as agent of modernization in the absence of a well-entrenched and shared industrial culture ${ }^{14}$.

\footnotetext{
${ }^{14}$ See my article Italy: the idea of a dynastic capitalism, "Social Compass», 1980; for a constant on-going critique of the centre left, cf. my contributions as deputy in the third legislature, 1958-1963; Nelle fumose stanze. La stagione politica di un "cane sciolto", Milano, Guerini, 2008
} 
The long phase of gestation of the center-left experience was rich in surprises. The months before Fanfani's government, supported from without by the socialists, were amongst the most tense and disturbed, showing the tangle of internal lesions, the conflict of interests and the opposing pressures which the project of "opening to the left" was feeding. The revolt of the "dorotei" and the crisis of internal equilibrium in the DC (1959) seemed to be healed with the victory of Moro at the congress which ratified the choice formally denoted as the "center left".

There were the months of the promulgation of the Green Plan, seeking to re-establish rural socio-economic balances ravaged by the exodus and by the fall of rural incomes. The need for change also involved key sectors in the organized catholic world, like the ACLI, crossroads between social and subcultural identity, and the first to propose the incompatibility between union and party appointments.

The cultural renewal of the catholic world was moreover a sign of the times, in that it was in 1959 that John XXIII announced the convocation of the Vatican II Ecumenical Council ${ }^{15}$. The first months of 1960 marked an acceleration and then a dramatic increase in the tensions running through the political system in a delicate transitional phase. The support given by the MSI (neo-fascist party) to the weak government headed by Tambroni unleashed a public outcry that peaked in the disturbances in Genoa and in popular demonstrations with deaths in various cities and a vigorous mobilization of "historical" anti-fascism, flanked by youthful supporters, unionized workers and intellectuals.

This anti-fascist upsurge was a social signal of intolerance which indirectly gave impetus to the center-left project. At the end of 1960, Fanfani formed a government which for the first time benefited from socialist abstention. The "economic miracle" seemed to provide the structural bases for an experiment intended to be a balanced but courageous one. The "Financial Times»" positive judgement was remarkable, regarding the lira as the most stable Western currency. The Rome Olympics were presented as a showcase for the Italy of the boom. Meanwhile, also in the unions important dynamics were a situation od almost full employment, increasing its contractual power, and leading it to call for a different distribution of profits (even through the gao grew between "protected" workers in the big firms and the employees of small, peripheral enterprises, almost wholly outside union protection). A symbolic data was that of Christmas 1960, with a public watch for the contract of the Milan electromechanical workers. This was a demonstration that brought out in public a new social force, anticipating the tensions and language of the subsequent decade.

${ }^{15}$ On Vatican Council II and its difficult development, cf. my Una fede senza dogma, Rome-Bari, Laterza, 1990, especially the first two chapters. 
The need of a different governance for society, moreover, was recorded by the 1961 census, which marked, statistically, areas of social suffering and distorted development, with a background of giddy demographic increase and accelerated urbanization, there were experiments in the center-left with direct socialist participation in Sicily and communes such as Milan, Florence, and La Spezia (1971). The Christian Democrat left interpreted as an encouragement that year's absolute majority obtained in the Sardinian regional elections by their party. In this period, Italy experienced the first triangular meeting between government, unions and industrialists, which seemed to initiate a new style of proceeding and a plan for more mature industrial relations, reflecting increased union bargaining power.

1962 was an important year on the road leading to a new political set-up. Despite support from the extreme right for Segni's election to the presidency of the Republic, and the death in mysterious circumstances of the manager, and advocate of the urgency of the new strategy Enrico Mattei, Fanfani managed to form the first government with external support from the PSI. the program was ambitious and, for a while, not devoid of real achievements. State pensions were increased, and the system of compulsory education reformed; fragments of a rudimentary welfare system welfare system were enacted - a late arrival in an Italy convulsively and chaotically entering into industrial society. An anti-mafia commission was even set up. However, the provision of most economic and political weight was the nationalization of the electricity, and this caused worried reactions in still-powerful sections of the entrepreneurial establishment, along with one of the most massive transfers of financial resources known in national history.

The opening of Vatican Council II helped feed the feeling of novelty and expectation by proposing a cultural thaw, destined to various, interesting development. However, clear definition of the objectives seemed to be lacking.

The 1963 national elections were an initial testing-ground for the new political balances. The DC lost clearly, but not unexpectedly, and this did not prejudice its leading role in transition. The socialists maintained their parliamentary strength. The liberals, representing the leadership of the anti-nationalization campaign, doubled their vote. The $\mathrm{PCl}$ gained nearly $3 \%$, backed now by a prestige and social rootedness that made the strategic hypothesis of a breakthrough on the left, reappearing among the moderate forces, problematic - a hypothesis almost like a declaration of purpose in the face of the right within. At the end of 1963 the first "organic" center-left, with the participation of the socialists, took shape. It was headed by Aldo Moro; Pietro Nenni was vice-president. Wage equalization, intended to review the working status of women was passed. However, the abolition of the standard deduction seemed to many commentators to sound a warning regarding the possible decline of the new government's projects. Meanwhile, a phase of recession took shape, which was to 
last all 1964, hastily described as "circumstantial", almost a passing accident as regards the lines of the "Additional Note", in which Ugo La Malfa in 1962 had designed the economic strategy of the new government, this was drawn up in a perspective of social alliances inspired by the spirit of efficiency and planned productivism.

This did not concern merely passing clouds. The recessional phase interrupting a long wave of expansion pointed to structural distortions not provided for in the model of development. In the 1964 two economic provisions were emblematic of the situation now heralded: the reduction of hours for 50,000 employees in big industries, and the decision to build an immense steel complex at Taranto.

The centre-left, inspired by a philosophy of expansion and re-distribution, had to come to terms with a new situation, the result of the socio-economic dualism and the new international role of the Italian economy. Social mediation and state investment remained the twin pillars of the government's response, to which added the belated enforcement of the agricultural agreements. Planning receded and was reduced to a propaganda slogan showing its unresolved cinbtradictions also at the level of theory.

The responses to the weakening of the reformist impulse were not long in coming. The Moro government fell in a provision for school finance. The summer of 1964 witnessed phenomena never fully explained. In the "Sifar-De Lorenzo case" there surfaced a couptype threat to democratic institutions which, aside from its own real force, showed the existence of worrying fragility and tensions in decision-making apparatuses of the state. President Segni was forced to resign following a paralytic crisis. Saragat was to succeed him, elected by the vote of the left after a brief interregnum by Merzagora.

Still in 1964, Togliatti died. His funeral, through its solemn majesty, confirmed the social presence of the $\mathrm{PCl}$. His testament marked an ideological watershed, almost a point of no return as regards the divergence between the Soviet model and the "Italian road" to socialism.

The year ended with a political scene torn and disturbed. The left of the PSI carried to its extreme the critique of the party's "social-democratization", splitting away and forming the PSIUP.

If Italian politics was disturbed and some cracks appeared in the mythology of the boom, the socio-cultural integration of Italians in consumerism and its trappings seemed to know no pause. Private car ownership proceeded at a pace comparable to that of pre-war America. Imported fashions and life-styles spread, often provincially exaggerated. The jukebox in every bar was a formidable symbol of identification. Domestic appliances entered (almost) every home.

Mass culture fed off stereotypes of every kind. Advertising became a major aspect of customs. The twist was the rage even in the old dance-halls. In 1962, Celentano was 
the first Italian songwriter to land on the mythical Paris Olympia, though Tajoli still triumphed with his warblings at Sanremo 1961.

The cinema transmitted a seductive image through the world, a basically reassuring one, in La Dolce Vita (1961). It is strange that even recently a catholic daily, "L'Avvenire", February 1990, pointed to Fellini's film as the most important emblem of the erosion of moral principles that were to lead inevitably to today's nihilism.

Films of social protest (Rosi) were accompanied by the sophisticated studies of Antonioni and Visconti. They were years of artistic creativity and "Italian style". Our design and fashion exports triumphed. But Alberto Moravia's La Noia marked a crisis of existential values, imprinted in the smooth image of the miracle. Natalia Ginzburg attempted an original autobiographical account in her Lessico familiare. Pasolini was confirmed as film director. Strehler offered the public Brecht's Galileo in the same year (1963) that saw the founding of Gruppo 63.

The record industry boomed. A young, mixed audience consumed the national songwriters (in the emblematic case of Luigi Tenco), went wild for the Beatles and the rising star of the Rolling Stones. Mick Jagger discovered for them the attractions of American folk and country, in a total integration of tastes and international generational fashions. In 1964, the year of Pasolini's I/ Vangelo secondo Matteo, the Italian cinema invented the spaghetti Western, edited by Sergio Leone, former assistant to Rossellini and Fellini.

TV was by then a widespread consumer item. It expanded the spaces for social communication and posed complex problems for those same forces checking it with sharp-eyed attention. In 1960 there was initiated a TV election forum, which apparently upset the minister Scelba's integralist dreams. The TV first carried to peoples' homes the great tragedies of the nation, like the rail crash at Voghera in 1962, and especially the Vajont disaster (1963). It was again the TV picture that sanctified the great public works of the period: the Mont Blanc tunnel, the Autostrada del Sole intended to "shorten Italy" (1964).

The Italy of parades and inaugurations, however, concealed with difficulty the skeletons in the cupboard. The scandal of Fiumicino - shortly conveniently "re-defined" exploded. In a bout of moralization Felice Ippolito, supporter of a national energy plan opposed by powerful economic and political forces, which boasted the "seven sisters" of the oil companies and the Hon. Saragat - was sentenced to 11 years. Censorship too watched over artistic production. It hit, for example, Giovanni Testori's Arialda, staged by Visconti in Milan, or the TV appearances of Dario Fo, in a regurgitation of repressive clericalism which was to be derided by the spreading liberalization of customs, inevitably brought by consumerism - but not politically fought or countered. 1964 was also the year of the first shy topless. 
It was the year of a polemic on the work of Franco Fortini, presented at Spoleto, Bella ciao, dedicated to the culture of the Resistance, which says much about the latent humors of the conservatives of the day, only four years before the explosion of 1968 . Political "folk", which was to provide the soundtrack of 1968, was born precisely around 1963, from the research of Della Mea and "syncretism" with mass musical culture.

Publishers turned to a public showing signs of diversification and development of taste and interests. Wittegenstein's Tractatus was started, and these were destined to reach a public which was unused to bookstores. The psychoanalytical intimacies of Berto's Male oscuro was the final product of the literature of the period.

- The unresolved contradictions become worse

The interlude of recession in 1963-4 seemed to give way, from early 1965, to a new expansionist phase of the Italian economy. In fact, this was a partially "drugged" resumption, caused by deflationary measures which produced a crisis in employment, as well as by the diffusion of the "pull 2 effects then produced by the EEC engine. The structural causes underlying the recurring difficulties of the economic system were thus essentially concealed. The failure of the 5 -years plan proposed by Giovanni Pieraccini taught the ruling class nothing. We were lulled by the OEEC figures which gave Italy first place in the world in 1968 for overall income growth since 1955. However the unresolved contradictions remained, and possibly worsened.

Among them was the essential immobility of a political setting dominated by the ongoing decline of the center-left experience into a mere formula for maintaining the power balances and the political stratum these expressed. There was also a latent crisis of the parties which, for good or ill, had directed Italy's transition to a "mass democracy", however fragile and limited.

This period saw the brief trajectory of socialist re-unification. The DC (Christian Democracy Party), which had been able to dominate the process of "cliental" transformation of the Southern political system since the early '60s, never losing touch with the catholic, subcultural environment or giving up its continual work of interclass mediation, saw its historic relation with collateral progressively crumble. Above all, its overall ability to manage and resolve the contradictions of a largely urbanized and "modernized" society, collapsed. The PCl too, though seeing its institutional and social presence strengthening, was riven with tensions and ferments which were to come into often dramatic contrast with the contesting outbursts of the late '60s. Moreover, the phenomena of cultural secularization brought out the unacceptable backwardness of the laws on civil rights, by way of an emerging organization of opinion and pressure which was to represent a primary element in de-structuring the traditional political conflict. Thus, this was not only a matter of internal processes of transforming the 
parties and party form, according to the political science typologies abounding in the early '70s. The nucleus of ' 68 should be traced above all to widespread, deep, social dynamics, and non-contingent causes which found in current conditions reasons for revolt, idealistic referents and even new codes of communication.

The collective mobilizations from 1967-1969 had their initial epicenter in the universities: not by chance, as the university was the place where cultural tension caused by social transformation burst out. It was caused too by the disappointed expectations of the aspiring intellectual stratum, the backwardness and inadequacy of traditional political mediation, and the remains of a Bourbon authoritarianism which was to be the fuse of the revolt. The crisis affecting the young educated generations should thus be referred back to complex motives and widespread disquiet, in an unbalanced, divided society. It set forth a potential conflict with the social order that was certainly not drawn up on traditional class identities, but soon adopted the symbols and theoretical models, often already obsolete, of revolutionary class action.

Once more there came into play the distortions of the development and the lack of a political filter able to give logical and concrete replies to the forces in the economy and the tensions of a society that was very mobile and not uncreative. To this was counter-posed the monolith of permanent mediation, the postponement of decisions, and the immovability of the political class. 1968 demonstrated the fall of the social representativeness of political representation, although its elitist view of power relations (through symbolic personalization and anathematizing of the "system") prevented it in Italy and elsewhere from building an effective political alternative.

'68 overthrew no government, but did undermine the "governability" of the various political systems in which it developed and which it opposed. It was a weighty subject of destabilization with a paradoxical conservative function as regards the internal balances of the Palace, and clear interactions with processes of cultural modernization and aspirations to a real democratization of the civil order. These were characteristic of a society such as the Italian, the day after its leap into industrial society. In this sense, its relative inability to plan refers back to the character of this spurious modernization, the weakness of a tradition of democratic, reforming organizations, and the persistent rhetoric and sectarian tendencies typical of the political system.

The students' ' 68 also acted as detonator for the worker and union recovery which celebrated its triumphs in autumn 1969. It was a great organized movement which managed to invent new dynamics of representation. The internal commissions in the large factories were abolished, and the political figure of the "delegate" was born, if possible, as unitary expression during the phase of rapid demobilization of interunion ideological barriers. It aggregated social demands spread over the country and in urban settings, and often usurped the functions of the parties. It was a movement 
which struck roots in the new "structural" bargaining of the working class, less exposed to the threat of unemployment, more integrated into industrial culture and ever less subordinate to traditional subcultural membership, which was an expression of "fractures" now dimply perceived. Hence in brief there was derived the physiological pressure towards the unitary re-composition of the bargaining front, and in hindsight of its organization. This did not mature so much in the sphere of ideology as in the practice of conflict with employers attached to an often fugitive political power. The decade thus ended with a setting dominated by phenomena of collective mobilization and social tensions which post-war Italy had not yet experienced. In the impact with the new movements and their anti-institutional dynamic there appeared the unresolved problems of civil development and political culture.

This impact produced a latent but painful institutional crisis with divergences that were often unsettling, in the responses of power. Added to the divisions and cultural backwardness of elected political power were the internal divisions of the political stratum that was not elected and multiplied in the shadow of the state bureaucracy and traditional institutions. Thus, if the lower magistracy and local administrators often "opened" to the emerging demands from civil society, at times expanding at their discretion the spaces for legislative and financial competence, the upper bureaucracy often responded with corporatist defenses and types of reactionary resistance. The pressure from civil society, in short, contributed to a further splitting of the political system and institutions. In this framework, there appeared disturbing signs for the democratic order itself. In the shadow, secret powers gathered, tired of the tactic of the "rubber wall" whereby political power tried to resist the pressure of the movements, and tending towards openly repressive responses. These resistances and reactions did not function in a void. They were grafted on to the fantasies of coups by neo-nazi covens and the working of the international secret services, and even on to signs of an incipient counter-mobilization by the right, which was to have urban-bourgeois aspects in the Northern cities (the "silent majority"), and a local-populist profile in the Southern uprisings.

The bomb that went off in Rome and Milan in December 1969 caused the first deaths in a terrorist violence that was to stain the following decade with blood. They mark the cruel transition to a different, still more uncertain political phase. The recessive period in the previous two years encouraged a return to the idea of planning, the magic word that summarized the expectations of the center-left. The Minister Pieraccini was its spokesman in his 5-year plan which was to inject elements of managerial rationalization into the economy from 1965 . The plan did not succeed, and laid bare the intrinsic weakness of political will and the power of resistance to innovation. On the other hand, the law on "just cause" which restored prestige to the unions' role and in some ways anticipated the legislation of the "70s, was passed. 
The Hon. Loris Fortuna presented the first bill for introducing divorce into state legislation, a question that had important developments, in customs and the political system. However, the attention of public opinion was still disturbed by terrorism in the Alto Adige, where there was a new outburst of alarming proportions.

In 1966 there was a brief period of socialist unification, the belated product and rapidly decaying fruit of the center-left, and the daydream of radical restructuring of national political "equilibria". However, there was also tension in the ranks of the Christian Democrats, where Moro's leadership was challenged by the intolerance of Scelba's right. A minute PCd' Italia was set up at Livorno, in stubborn Stalinist faith, and this, in 1966, anticipated the foundering in parties of some post-' 68 experience. The industrial colossus of Montedison was set up amidst suspicions and polemics. Fiat made an important agreement with the USSR for the building of a "car city", Togliattigrad, that was to be followed in 1989 by Gorbachev's "perestroika". In 1967, Fiat reached first place for auto sales in Europe. Meanwhile the government experienced another dramatic and significant defeat on a measure concerning the setting-up of state nursery schools, confirming the resistance met with by even the timid legislative innovation of the time. The university of Rome was the setting for neo-fascist raids, during which the student Paolo Rossi was killed. The reaction was immense and widespread. The first sit-ins in academic buildings occurred. In the spring of 1967 there was a series of occupations prefiguring the mobilization of the following year. In the press and parliament the accusation in the SIFAR case three years before exploded. Alto Adige terrorism caused more deaths, but diplomatic mediation to defuse its subversive potential was intensified, especially through the direct negotiations between the Italian and Austrian governments and the devolution of autonomous powers. Between the end of 1967 and 1968 there were international occurrences which were to have significant effects internally; from the military coup in Greece to the Tet offensive, the French May to the Czech spring, and the assassinations of Guevara, Robert Kennedy and Martin Luther King. This was a dense, complex mass of ideas, facts, symbols and hints, which nurtured phenomena that were to lead to the accelerated collective mobilization of 1968.

In Italy the last regular end-of-term national elections were held. The two major parties were again strengthened. The recently-united socialist party suffered a heavy reverse to the benefit of the secessionist PSIUP (Partito Socialista Italiano di Unità Proletaria). Electoral failure hastened an internal crisis. In 1969 the "nth", provisional "unitary" interlude of Italian socialism ended. Social tension rose. There were deaths at Avola and Battipaglia in a recurrence of Southern rebellion that shook public opinion and produced new political difficulties. At the end of 1968, the union federations organized the first unitary general strike. A few months later the anachronistic "wage cages" were abolished, against which the union movement was again united, laying 
the premises for the wage-claims of the bargaining period in autumn 1969, known as the "hot autumn". Judgements of the Czech affair deepened the gap between Italian communists and the Soviet leadership (1968). The explosion in Piazza Fontana, 12 December 1969, was the tragic counterpoint to a huge workers' demonstration at the end of the year.

These five years were shot through with events and phenomena marking an acceleration of overall cultural dynamics. The young Sicilian, Franca Viola, in 1965 refused the traditional "reparation marriage", and thereby pointed to a decline in the community apparatuses of social control, still largely operational in the pre-industrial periphery of society. The year after, the young "long-hairs" became the "angels of the mud", in rhetorical terms, after the Florence flood - almost an ethico-aesthetic legitimation of the new youth universe. And yet, the same year in a Parini high school in Milan a "Zanzara case" blew up after a harmless survey on adolescents' sexual ethics. This revealed the persistence of an archaic and dully repressive "common sense" coexisting with modernizing demands. Moreover, TV censorship in all its forms still raged. Even the ditties of Gianni Morandi and Carmen Villani paid the price, adjudged too "politicized" because of vague references to the Vietnam question, disturbing world "equilibria". Many art shows and cultural performances, on the other hand, already had a contestatory air. There were dramatic incidents, like Guttuso's rejection of the invitation to the 1966 Venice Biennale, or the resignation of Strehler at the Piccolo Teatro in Milan, or the alternative theatrical circuit set up by Dario Fo and Nuova Scena, 1968, heralding the period of alternative cultural cooperatives in the immediate post-' 68 period.

However, there was also a development in tastes and expression involving a relatively wide public, unfailingly harmonizing with the new politico-cultural attitudes of the young. Free jazz triumphed in Bologna, when impresarios had judged it no-commercial. There was political or semi-political cabaret. The Berliner Ensemble played at Venice (1966), and the irreverent Orlando Furioso of Ronconi (1969) was a success.

The cinema of the period is rich and often original. Alongside Fellini and Visconti's masterpieces we find the efforts of politically committed directors, or at least those aware of the social implications of existential disquiet. It was the time of Gillo Pontecorvo, Marco Ferreri, Liliana Cavani and the beginners, Marco Bellocchio (I pugni in tasca, 1966) and Salvatore Samperi. It was the shining moment for the new political song, promoted by Paolo Pietrangeli. Vitaliano Brancati's La governante made a scandal on the stage. But real scandals were not lacking, often troubled ones, news of which now had resonance in a less conformist press, more alert to the languages of social communication. 
Inquiries into the assistance for earthquake victims at Belice (1968), the "Lavorini case" and the Felice Riva affair (1969) shook a public opinion driven by a mobilization that often swept away the rhetoric of the boom and initiated a phase of criticism and individual and collective disquiet.

The processes of religious "laicization" went forward, often by being superimposed on the growing politicization. This was the case for don Lorenzo Milani and his Lettera a una professoressa, published in 1967, and of the Florentine community of Isolotto, examples of a religiosity seeking embodiment in the social. Meanwhile, indifference regarding traditional liturgical practices grew. Even Paul VI's encyclical Humanae vitae fell on the respectful indifference of the many, despite the objective provocation this contained in view of contemporary morality and its complex social reasonings, rather than ethic-theological ones. There followed a renewal of cultural models. Basic works of contemporary thought by Lévi-Strauss, Barthes and Walter Benjamin were translated in these years.

- A technically advanced society, but lacking in positive political mediations and critical cultural filters.

The "70s were certainly one of the most critical periods for Italian social history, aside from any more circumspect historiographical analysis. They were years when the tensions and contradictions of economic expansion lacking a political filter and parallel civil development, settled into an explosive mixture, with the new needs of a society being now considered, in its own way, as "industrially advanced".

The tensions, the contradictions, the emerging social needs, were located, with explosive results, on a background dominated by the world economic crisis. The energy question, the modification of exchanger rates, the oil crisis - these were reinforced by political subject alternative to the established political forms. In this perspective, an increasingly evident crisis of representation took shape - threatening to collapse the institutional balances themselves.

Political society underwent an accelerated and disconnected "re-definition", whose principal feature was a growing overall instability. Between 1969 and 1973, without expansion of the industrial productive base, Italy saw its residual socio-economic identity linked to the soil and agriculture, disappear. In 5 years almost 750,000 labourers left the fields, swelling still more the trend to spurious urbanization, faithfully recorded in the 1971 census. It also marked the last phase of the demographic boom, prior to the radical inversion of the tendency, appearing halfway through the decade. Italy swiftly became "tertiarized". Industrial employment tended to stabilize, while workers' wages now almost equaled the European averages. 
Counterposed to the flowering of collective movements developing in the crisis of old subcultures and tending towards an acute politicization of social demands, we had an immobile, divided political system, essentially concerned about its own survival in a new, fluid context which eroded the margins for institutional mediation. This tendency explained the real, traumatic impact with the institutional political system. At the same time, this exposed the system's fragility, as witnessed in the swift decline into parainstitutional mini-parties or support structures for subordinate political participationism on the part of the social movements.

The movements involved the whole of society with demands latent in the distortions of development and, notwithstanding their heavy, often misleading, ideological mantle, they expressed a new essence in the dialectic of institutions and civil society.

Indeed, at bottom there was a critique of institutions and the apparatuses of cultural reproduction which, not by chance, spread out from schools into the "separate bodies" - hospitals, jails, asylums. Experience of popular participation spread through the country, often having as their referent the "new" union if councils. A result of this novel pressure on the politico-institutional system was to be a legislative output which tried partly successfully, to channel pressure for renewal into the traditional course of subaltern participation, favoring by law the transformation of organizations "of solidarity" into interest groups, according to the standard definition of sociological functionalism.

A process of enlarging citizenship was undeniable - if we carefully take note of the implications of its reactive strategy - acting on the system of law (first laws on civil refights, divorce conscientious objection, legalization of soft drugs, etc.), and that of formal representation. The belated enforcement of regional government, extending the vote to 18 years old people, institutionalizing consultative bodies in schools, and administrative decentralization in major urban centers are emblematic. Aside the two demands was the Workers' statute of rights, revolutionizing a right to work halted for decades and now implicitly and formally legitimizing the general role of the union, not without reactions from the other side (employers' resistance divergence between public and private enterprises in one hand; in the other, increased bargaining disparity between "string" working class, and the unemployed, under-employed, and employees of smaller firms). The union, moreover, still enjoyed a social mandate that was to be brusquely rewritten with the recession and the tension produced on the political system. It was the union, in this phase, which acted as interpreter for demands not strictly for wage rises (the 150 hours of education, for example), raised the banner of anti-fascist mobilization, and broke the dikes of inter-party mediation, going so far as to hit at dealing with new qualitative issues (the condition of women, life in the metropolis, alternative culture). 
However, the effects of reaction and retro-action to the pressures the '60 and ' 70 s on the system were not slow to appear, and in worrying form. The growing bargaining stubbornness on the side of labour soon appeared a real boomerang for a policy on management of a work-force not "guaranteed" and increasing rapidly, for example. On the political side proper, the enactment of decentralization was accompanied by the explosion of rebellions in the South (Reggio Calabria) revealing the weakness of mere institutional responses, and making room for neo-fascist counter-mobilization. These street rebellions were resolved into frustration and derision (the "Colombo package" for employment in Calabria, the folly of Gioia Tauro, etc.), amidst ripples of peripheral "municipalism" (I'Aquila, Eboli).

Above all, one saw a growing political violence, ambiguous and dangerous, which rapidly dissipated the illusions of those who interpreted the bombs of 1969 as the classic last throw of the political upheavals of the time. These were years of terrible massacres, with goals of destabilization and the spreading of social concern manipulated by secret forces and those opposing change; these were also the years when Red Brigade terrorism made its first moves, inspired by the criminal intent of making the crisis and degeneration of the political system bloodily visible.

The election of 1972, the first elections called before time in the postwar period, were held in a climate heated by the Feltrinelli case, and the dramatic revelations concerning the Piazza Fontana affair. The election result partly confirmed that of the regional elections in 1971, with an advance of the right in the South, but the two major parties holding, a prelude to the polarization recorded in subsequent votes.

The crisis of the reformist strategy was symbolically summed up in the return to a tactical center-right headed by Giulio Andreotti, the man of the future "national solidarity", open to the $\mathrm{PCl}$. It was a defeat for the new left, seeking representation outside the channels of the historic parties. The PSIUP disappeared, and there was a fall in tension leading to the shipwreck of the minor parties of the extremes.

The alternative to a courageous act of renewal was generally a corporate retreat built in the growing segmentation of interests of specific strata, and on the recession involving the economy after (but not exclusively because of) the oil crisis of 1973. The re-constituted center-left enacted an unsuccessful "price freeze" and the austerity program of Sunday without cars, and switching off lights. A feeling of collective insecurity grew, coupled with the creeping crisis of social legitimation, now involving unions and new movements. There was cholera in Naples. At Brescia and on the Italicus express terrorist strategy reappeared (1974).

However, the 1974-5 period was also one of re-grouping and redefinition of diffuse demands which sought responses not yet tried. In this climate was prepared the victory for divorce in the referendum organized by the catholic right, and which produced 
a political "break" not reducible to the old schemas. It transmitted to an almost incredulous ruling class the picture of an Italy, especially urban Italy, modernized by routes and channels different from the traditional ones hegemonized by the Church and the subcultural parties. These phenomena should be held responsible in part for the electoral pressure (the 18 year old people voted for the first time, but this was not decisive for the results) which gave the left control over almost all the major urban centers and many regions, on June 15, 1975.

The legislation of the decade began with important provisions. Within a few months, parliament approved the introduction of a divorce bill, and the workers' Statute of rights. An effective start was made with the normal regions, whose political birth was troubled by parochial Southern riots which revealed the persistence of a relation of hostility and distrust regarding the state. The revolt witnessed very serious events, and was soon taken over by circles of the subversive and populist right. The intervention of military made units was necessary in Reggio Calabria, a city besieged.

These were times of constant political violence. During incidents in the streets at the end of 1970 the Milan student Saltarelli was killed. In 1971 the state university of Milan was again the site for bloody clashes between youthful demonstrators and the police. There was also a right-wing response organized in the streets, with nostalgic overtones. The first regional elections saw support for the MSI in the South. Leone was elected president of the Republic with a decisive backing from the parliamentary extreme right. There was talk of subversive acts plotted with the complicity of circles within the state apparatus.

The publisher Giangiacomo Feltrinelli died in mysterious circumstances at the beginning of 1972, whereas the investigation of the massacre in Piazza Fontana revealed a background that led to the uncovering of a "black track" (fascist). In a climate of great tension, with rumours and signs of the wearing down of the institutional framework, elections for the Houses of Parliament were held. The resistance on the $\mathrm{DC}$ and $\mathrm{PCl}$ support showed a polarization that was to last. The right gained. Expectations of the new left represented by the crisis of traditional subcultures, were disappointed by the electoral reverse of the Manifesto group and the MPL, and the PSIUP's negative record.

A few days after, the police commissioner Calabresi, principal in the first investigations of the 12 December 1969 massacre, was assassinated in cold blood. His funeral took place in a Milan on guard, with a showing of the "silent majority" seemingly inclined towards openly authoritarian positions. The climate of emergency pressed upon the political "equilibria". At the end of June, Andreotti revived the center-right, winning a precarious majority in parliament. Union unity proposed a new goal. The unitary CGIL-CISL-UIL was created in July 1972, the political result of an integration forged 
in the workers' struggled, and seeming to indicate a point of non-return. Te world of commerce and production was troubled by the introduction of VAT, supposed to align Italy with community legislation and mark a possibility of battle tax evasion.

The front of civil rights was moving slowly. A law allowing conscientious objection was approved, and preventive detention was restricted following the "Valpreda case".

Again in 1972, Enrico Berlinguer took over as secretary of the PCI. With the Macchiarini kidnap the "red brigades" trademark appeared. On the trains carrying union delegates to the south for a united national demonstration, explosive devices were found. Violence raged in 1973 too, a year opened by the tragic death of the student Roberto Franceschi during clashes with police in Milan, followed by April's neo-fascist disorders (days of the fire at Primavalle in Rome and the riots in Calabria), and with the attack on the central police station in Milan with its protagonist the "anarchist" Bertoli. Rome airport, Fiumicino, was the setting for a bloody guerrilla attack by fedayin.

In July an organic center-left government under Rumor was formed. It was at once at grips with a cholera epidemic in Naples and the South, and with the energy crisis, which was to bring austerity. Berlinguer attacked the censorship by the Soviet press of one of his speeches in Moscow.

The now serious economic crisis, with a foreign debt out of control accentuated the fragility of the political scene. There were three governments in 1974, with acrobatic taking of sides and formulas that could not hide the progressive de-legitimation of "equilibria". Revelations of coup attempts continued. These had affected important organs of the state apparatus. Meanwhile, the challenge from "black" terrorism continued (massacres of Piazza della Loggia and the Italicus) and the Red Brigades intensified their activity. 1974 was the year of the Sossi kidnap, and the arrest of Curcio, who escaped after a few months.

The referendum on divorce of 12 May 1974, which the parliamentary political forces had tried from the start to avoid, was won by the "anti-abrogationists", with $60 \%$ of the vote. In the same year public financing of the parties was enacted, and the decrees on educational democracy ratified. Berlinguer set against the erosion of the traditional parliamentary balances the hypothesis of the "historic compromise" which was to mark a controversial turning-point in communist policy.

There were important local election on 15 June 1975. 18 year old people voted in them for the first time, and a climate of expectation and disquiet was widespread. It resulted in a vote to the left, sufficient to change local political forms in regions and cities. Almost all the major urban centers voted in left-wing governments with communist participation. The DC's crisis was deep, even if it was not the electoral collapses prophesied by the new press opinion-makers,. Christian Democracy 
entrusted itself to the inflexible image of Zaccagnini. Meanwhile, the political setting saw a rapid eclipse of groups and parties which had tried to head-off and bestride the social movements of the early '70s. Marco Pannella's provocative charisma dawned, prefiguring an anomalous party form, the radical, based on the society of spectacle and declared refusal of social representation within the institutions. However, the continuing erosion of traditional political and para-political organization, even that inspired by the most explicitly "political" subjects of '68, gave way tom the emergence of issues restricted until then by rigid ideological loyalties. Feminism, ecologism, and the anti-nuclear campaigns expressed a de- and re-structuring of the political arena such as to foretell a period of a "return to civil society", too hastily and summarily labeled a "retreat".

Culture, custom, press reporting (mostly crime) of the period confirm the image of a society not free from schizoid trends, and its own paradoxical creativity. The early ' $70 \mathrm{~s}$ gave us the politicization of film drama (as in Elio Petri's Indagine), Dario Fo's satiric inventions, Nanni Balestrini's alternative fiction, and the success (also a commercial one) of political "folk" (the concerts of the "youth proletariat", the Inti Illimani). The interaction between art, drama and politics was shown by the new songwriters Villani and De Gregori, in the example of Umbria jazz, even the incidents surrounding the public concerts on the ARCl circuit, or the "alternative festas" (like the dramatic ones in 1974 in Milan, to hear Lou Reed, without charge).

Paul VI proclaimed the undoubted existence of the devil to a public opinion divided over the question of abortion, aroused by the arrest of doctors who practiced it openly to condemn the plague of backstreet practice. Within the catholic world, shaken and divided by the referendum, the affair of Abbot Franzoni and the community of St Paul was brewing.

The Nobel for Montale was celebrated whilst experimentation with avant-garde theatre continued, with prestigious international recognition. The Taviani brother had a success in Allonsanfan (1974). The next year, Pasolini made an apology on violence (Salò) which preceded his own murder by a "child of the slums" by a few months. The headlines were not short of episodes of violence, cloudy, with lurking political implications, like the "Circeo massacre", attributed to fascistic young scions of the upper Roman bourgeoisie (1975). These were the years of cholera and the toxic cloud of Porto Maghera, of telephone tapping, and the emergence of a gigantic "Sindona case". The "reformed" RAl experienced some periods of freedom from the stifling guardianship of political power, soon, however, re-cast and brought back into neat (though "correct") political parcels. After the experiment of Telebiella the interlude of cable TV suppressed bureaucratically, the real novelty was the outbreak of private radio, legitimated first in fact and then in law through the unexpected swelling of its audience. Variations on this theme were to be infinite: from alternative radio to the 
most shamelessly commercial broadcast, from self-managed and highly politicized experiments to non-stop rock stations and personal on-air dedications. The monopoly circuit of communication was broken, opening up a phase of legal chaos and social and political pressure of all kinds, where the new frontier of private TV was rapidly to appear. This was a phenomenon soon to produce important results, grafted on to an exceptional expansion of TV user-time, and on a rapid commercialization of technological innovation which modified in individual behavior (color TV, the remote control, the profusion of channels, etc.).

Italy too entered the age of the mass media and the image, and found itself at once at home. In a period when it is no longer so much the contents that count, no one seeming to have time to think about them any more, so much as the containers, where packaging seems more important than product, the homeland of bel canto and the bella figura moved easily, and - finally" - felt at home. I am not just thinking of haute couture made in Italy which closely challenged French primacy. Italian terrorism itself demonstrated great refinement in using the mass media, especially TV, as its stage, sounding board, and political platform. The theory of violence as "visibility" found in this instance a conclusive proof.

There was an explosion of politics-as-spectacle. It was tragic that in Italy it was to explode in times of mourning, particularly the funerals of Togliatti and Berlinguer, and primarily the funeral mass for Aldo Moro, kidnapped and killed by the Red Brigades; Paul VI, a shy and intellectual pope was present in San Giovanni in Laterano, appealing and accusing God directly, enthroned in the glory of the basilica and clothed in liturgical vestments but seated like new Job, on the dung heap of human misery.

With terrorism, society, as it were, contracted. People rarely went out in the evenings. The very police escorts who guaranteed the safety of public figures helped to keep them far from the people. The gap between representative and represented widened, between government and citizens, authority was increasingly distant.

There was also a symptomatic fall in the publishing of books of comment. The reason as regards the public at large may be guessed: whatever can writers and commentators teach if they have not foreseen the Moro case? In the evening, the city streets were often deserted. There was a kind of contraction of society. Only in the warm bosom of the family and with personal friends did one find the traditional refuge, safety, and conversation.

However, the reaction from Italian vitality was not long in appearing. The thousands of Italian cities and towns, the "little homelands", quickly revived and became lively. Not even terrorism could tear the basic social fabric. The new socio-political and cultural climate, the season of the ephemeral, was linked to the "Roman summers" of a young Roman architect and communist councilor, Renato Niccolini: great performances, 
almost free, in the open, giant screens where classics like Abel Gance's Napoléon were shown, at the Circo Massimo or the basilica of Massenzio - concerts and dance, from rock to old-time, at Villa Ada and in the ancient villas. Provincial Italy re-awoke with local carnivals, the festivities of traditional folklore, the re-discovery of dialects and old customs.

On the political plane, the Moro-effect involved collaboration between communists and Christian Democrats, red and white flags started to flutter together, crucifixes and hammers and sickles were intertwined. The famous "historic compromise" set out by Berlinguer after bitter rumination on Chilean events and Pinochet's bloody coup against the Unidad Popular government of Allende, and with the careful, precise counsel of the leader of the Christian left in the immediate postwar period, Stefano Rodano, took shape. It finally became a reality over the still-warm body of Aldo Moro. One might say this sacrifice was needed so that terrorism should begin, after undoubted success, to experience a rapid, vertical drop.

The figure of the "penitent" was born, essentially catholic and Mediterranean, child of a culture where confession and pardon are family institutions to be venerated. It is not a mystery that the end of terrorism should have coincided with its triumph. Recruiting en masse, selectivity declined, and the unstable, the insane, the timid and the unsure embarked, destined to end up in the note nets cleverly cast by Carlo Alberto Della Chiesa.

Later, against the mafia in Sicily, the game was to be harder, and would not permit such shining successes. Indeed, for the general, now "anti-mafia-prefect", there would come first isolation and then death in a pitiless ambush. It was a game that, despite partial and temporary successes, still remains open with uncertain previsions.

Meanwhile, society began to move forward. The economy experimented with new technologies and revised its industrial relations. The very power of the unions pushed employers to save labour-power to the utmost. Better deal with robots than the CGIL. It was a fresh demonstration that union militancy kept its counterpart on its toes and ended up strengthening capitalism.

Society as a whole revived. The nightmare of what Sergio Zavoli was to call in a TV series the "night of the Republic", was ending. The "system" had held, and had in some ways functioned. It was almost a masterpiece of flexibility, resisting softly but stubbornly. Italy was freed from terrorism without becoming a police-state, despite the "legge Reale" and the "exceptional measures".

Drama all'italiana began to produce evident and unhoped-for effect of civic sense. From Damiano Damiani's II giorno delal civetta (1968) we came to Nanni Moretti's efforts, often idiosyncratic but always interesting - La messa è finita, 1985, and 
Palombella rossa, 1989. Moretti was an acute, careful observer of the world of youth, but also of his own generation, of the ideological crisis of communism, and the turmoil affecting the catholic clergy, especially the lower clergy in the poor parishes of the unending, broken-down periphery of the new metropolitan centres. Generally, the cinema resumed its dialogue with society. It was no longer one of pure escape. It reflected the problem of a lively, dynamic everyday life, which still, however, lacked full self-awarness.

Collaboration between communists and Catholics, giving rise to the governments of national solidarity, lasted only two years. The PCl lost ground in the elections. Not much, but enough to terminate the experiment hurriedly. The PSI was afraid of isolation. The lesser parties feared their irrelevance. The institutional structure creaked. The more or less spontaneous movements made themselves felt, and aggressive. The radicals, and then the environmentalists, gained ground. The "end" of ecology reshuffled the cards of the political game, and proclaimed a post-ideological perspective. It was not enough to point to great new worlds, and general, macro-social reforms. It was necessary to link the great ideals to the everyday, immediate needs, and the battle against pollution.

The crisis of the institutions pushed forward individuals - Sandro Pertini, elected president by the parliamentary parties faute de mieux, succeeded in the impossible undertaking of making the office popular, at the expense of a touch of demagogy and some ambiguity, rightly exceeding the letter of the Constitution.

Over everything, from the dysfunction of the services to the mafia and organized crime in general, political and common, good "heartedness" prevailed, the improvisation, lucky star and good fortune of Italy. This time the lucky star had the shape of a football.

In 1982 Italy won the world cup in Madrid. President Pertini was in the stands alongside the king of Spain, Juan Carlos, but at Italy's decisive goal, he leapt to his feet, forgot etiquette and, king or no king, started to cut swathes in the air with great gestures of victory. As the victory of Gino Bartali in the 1948 Tour de France had saved Italy from "revolution" unleashed by the assassination attempt on the communist leader Togliatti, so now Italy found itself united and emotionally involved in another great sporting victory. The Constitution says Italy is a republic founded on labour. In reality, it seems like a republic founded on football. This enthusiasm is contagious. The jubilation of the 1960 Rome Olympics was repeated. However, in a society which did not spare its millions when involving the engaging of famous foreign footballers (the classic case is that of Diego Maradona the Argentinian, to Naples), whilst then being stingy over a few thousand lire for teachers and professors, social tension was bound to rise, especially in the public sector. 
Towards the middle of the ' 80 s, the traditional unions began to experience a crisis of representativeness. They were no longer seen their own members as representative. "Wildcat strikes" proliferated. The COBAS, "committees of the base" ${ }^{16}$, were born, in a situation where the principle of "hiring and firing", or one where there was freedom to fire, did not apply. Here, managerial authority had difficulty in making itself heard. Italian society seemed riven by violent corporate tendencies, in the sense of a fierce defense of sectoral interests, but also of a relatively novel tendency to place oneself above all the others. The crisis of totalizing ideologies, which on principle made the individual submit to the global design, was no longer just an intellectual question, but became daily practical behavior. Success at any price became now the tangible mark that the individual had value. Social solidarity faded.

Everything seemed to return to the "center". The reformist thrust that the radicals' initiatives had sagely set in motion and ridden for almost a decade, seemed to be extinguished. The braking effect paradoxically exercised on Italian society by terrorism - impoverishing the treasury for the armed escorts for public figures, clearly driving a path between elected and electors, discouraging all reform for fear of encouraging, even unconsciously, the new "subversives" - now made itself deeply felt.

The cold Francesco Cossiga succeeded Pertini in the presidential palace. Ciriaco De Mita, the "renewer" was at once prime minister and secretary of the DC. The "fiveparty" coalition, a government resting in the DC-PSI axis with the backing of the PRI, PLI and PSDI, had returned. This was an updating of the old "centrism", even though De Mita and the DC left seemed to want to abolish currents within the majority party and replace its cadres on the outskirts in an attempt at managerial modernization. This was inevitably to fail, and gave rise to a transverse alliance which found close alignment and perfect unity between the Dc's new secretary Arnaldo Forlani, and the "movementist" and untrammeled OSI secretary, Bettino Craxi.

The internal development of the catholic church seemed to copy on a magnified, world scale, a similar plan. Twenty-five years had passed since the end of Vatican Council II. The ecumenical legacy of John XXIII had passed to the strong hands of John Paul II after the troubled interlude of Paul VI. Karol Wojtyla is as modern in his use of the mass media and jet planes as he is conservative in his political and theological-moral position. He is the Polish pope, the pope from the trenches, who does not want to yield an inch of central control over the "ecclesial" committees of the base from Brazil to Holland, or from the American Catholics who do not accept bans on contraceptives, to catholic dissent in the base, which shakes France and Germany, but also Italy ${ }^{17}$.

\footnotetext{
${ }^{16}$ Cf. E. Lombardi, Cobas. Una spina nel fianco, Rome, Sovera, 1988, with my introduction regarding the meaning of the revolt of the base against the union leadership. Along with the student movements, the Cobas are for the late ' 80 s the sign of a growing disquiet in the social bases, in the context of a "blocked democracy" and static institutional structure, which tends to defer problems instead of trying to find their most functional solution at least coast to the collectivity.

${ }^{17}$ Cf. my Una fede senza dogma, Rome-Bari, Laterza, 1990, esp. Chapter 1 Towards the end of Christianity, and chapter 2 The neo-Constantinian temptation.
} 
The great ideologies whose roots struck into the nineteenth century cultural universe are dying. The $\mathrm{PCl}$ itself, on the wave of collapse in the "real socialism" of Central and Eastern Europe, believes it must change its name, with operations perhaps too redolent of public relations and photogenic cosmetic than theoretical and idealist consistency, however feeble.

One returns to the private. Public bureaucracy has failed noisily. State and para-state industries are up for sale - to a point. Is it a sense of decency or drama Italian-style? Romano Prodi, president of the IRI till the appointment of Franco Nobili (1990), handed over to the private sector all he could to fill the abyss of debts. After long negotiations with Ford, Alfa Romeo (Arese and Pomigliano d'Arco) went to Fiat, which had already taken over Lancia and Ferrari. Montedison allied with ENI, but this joint venture immediately seemed a mismatch. As regards the rest of Europe, Italian capitalism, despite having achieved progress unthinkable just two generations ago, is lame; I have called it "dynastic" elsewhere. Its lameness is dramatically worsened by public intervention which exacerbates its distortion and seems to use state enterprises and para-state agencies as a reservoir of votes and when needs be as emergency reserves from which to ladle out funds. The more alert observers are aware of this. Whilst novelists such as Paolo Volponi ${ }^{18}$ linger with wearily moralizing visions where personal bitterness prevails in principle over analysis and interpretation which artistic creativity could make clear and emotionally persuasive, there is no lack of commentators who show how Italy is today marked by a double distortion as regards the industrialized West. It is an essentially oligarchic private capitalism (few name and few big families - Agnelli, Gardini, Berlusconi, De Benedetti, etc.), a private, closed oligopoly, if not a monopoly; and a so-called "public" system. The latter in reality is an arch-fraternity of power that could be defined as "neo-feudal", if that did not offend historical feudalism, which was very responsible to its famuli and subjects, to the extent that the Colonnas could start a war against the Orsinis for offence given to one of their peasants.

This essential institutional immobility is reflected in the paralysis of the political centres, and the systematic referral back of major decisions. From the university world, which seems overpopulated and inefficient especially in the metropolitan areas, to that of the basic social services (housing, transport, hospitals), this stasis covers, beneath a cloak of surface tranquility, a social situation in slow, continual fermentation. This immobilism was soon complicated and brought to breaking point in the late ' 80 s, by the rise of new, unexpected situations which took the political class and the intellectuals by surprise. They were quite unprepared to face new emergencies: drugs as mass phenomenon and extra-EEC immigration.

The first emergency, that of drugs, marked Italy as having paradoxically progressed. From staging post, it had become a consumers' market. It had the certificate issued

${ }^{18} \mathrm{Cf}$. Le mosche del capitale, Turin, Einaudi, 1989. 
by the multinationals of the drugs trade - Italy had entered the ranks of the opulent society ${ }^{19}$.

As for extra-EEC immigration, especially coloured immigration from Africa and Asia, the Philipines and Capo Verde islands, it is a breathtaking phenomenon ${ }^{20}$. Commonplaces are shattered. And yet, how gently, cleverly deceptive are these commonplaces! One sinks down and sleeps as if in a comfortable armchair. For ages, perhaps centuries, we used to think that the Italians, certainly not without even serious faults, were nonetheless kindhearted, compassionate, human. Italians - fine people. Racists were those others, Germans, Nazis. It did not take much to discover that there are not just other people's blacks. First, Villa Literno: a crime one could still in good faith believe the bullying of a bunch of local toughs, to the extent that at the funeral of Jerry Masslo, the young black killed, the priest could ask, in fact rather unconvincingly, for forgiveness for the whole population. However, the recent events in Florence (March 1990), gang raids only apparently at random the arrogant statements of the minors arrested, who seem at first sight to have learned the right answers and been criminally prepared, can leave no doubts. Even two years ago, the abusive language used against a black woman in a Rome bus could be reduced to, and interpreted as, bad manners. This was my interpretation and that of the late lamented Cesare Musatti. Naturally, there was discrimination, with a racial background in that it was directed against a coloured person, but the very chance nature of the event encouraged us to put the event in a context of manners rather than conscious racism or deliberate ethnic conflict. This reductionism seems today, even though the intention was to defuse the situation, no longer arguable: it tends to favour the criminals.

This was a rude awakening. A people accustomed to export their labour force shows itself now deeply hostile and full of hatred, indifferent, exacerbated to the point of violence planned and also gratuitous, against immigrant colored workers. This labour force represented the raw meat of the youngest, especially from the South, forced to emigrate so as to escape, for themselves and their families, the chronic hunger and shortages of endemic poverty. At once one thinks that behind the events in Florence, as behind certain pseudo-sporting demonstrations with banners saying tersely "Hitler, the Neapolitans like the Jews", there lies hidden a political plan: a precise desire that follows a plan worked out and strictly controlled in every stage. We are not in France, nor yet in Germany. We do not (yet!) have a Le Pen. In my Oltre il razzismo - verso la società multirazziale e multiculturale ${ }^{21}$, I quoted examples and statements by French neo-fascists, who found their electoral fortunes amongst the pieds noirs, in former worker areas like Marseilles. (What would the ghost of the socialist Gaston Defferre,

\footnotetext{
${ }^{19}$ Cf. my Giovani e droga, Naples, Liguori, 1984.

${ }^{20}$ Cf. Stranieri a Roma, Rome, ed. Caritas and SIARES, 1989.

${ }^{21}$ Armando, Rome, 1988.
} 
for decades socialist mayor of great popularity in this great Mediterranean port, think of it?). In Toulon also, they have success among the followers of Charles Maurras' Action française, now under the banners of jean-Marie Le Pen's Front National. In that book I observed that Le Pen's $20 \%$ at Toulon, beaten only by the surprising landside in Marseilles, had spurred on those who manifest the pride of the français pur, especially veterans or those nostalgic for, the colonial adventures in Indochina, Algeria, the OAS, etc.

Let us leave aside the German situation, and England with its "citizens" from the exDominions of the crown. What is striking in Italy is the proud confession, almost the selfincrimination, of the young gangsters in Florence. I am aware there is a whole tradition, not merely literary, of "damned Tuscans" (maledetti toscani) and "barbarous Italy", two famous titles from the hidalgo Curzio Malaparte. I know too that not long ago in Rome, at Tor Bellamonaca, there were pitiful episodes of struggles between the poor. The inhabitants of the slum had risen up against the idea of equipping nomad, gypsy, encampments. I ask myself what the Hon. Pino Rauti, neo-elected national secretary of the MSI, means in his programme when he speaks of a "breakthrough to the left". What has he in mind? Does he mean to organize the "king's beggars"? Does he want to feed the insecurities and frustrations of the poor natives, supplement knowingly the irrational fear of being overtaken by the coloured poor, unleash a fratricidal war between the impoverished, perhaps speculating electorally on the eternal grey, mean world of bienpensant Italians? One must drop every attitude of suggestibility, such as that surprisingly referred to by the Hon. Laura Balbo ${ }^{22}$. One should in all humility and perseverance organize a whole policy of welcome for the "guest workers", without demagogy but also without pointless harshness, in the awareness that tomorrow's society for Italy too, will be multi-ethnic and multicultural.

${ }^{22}$ In Democrazia e diritto, 6, November-December, 1989. 